DOI https://doi.org/10.15589/znp2020.4(482).9

УДК 681.58

\title{
CREATING A PHOTOLITHOGRAPHIC MASK OF PCBS USING ADDITIVE 3D PRINTING TECHNOLOGIES SLA DLP AND LCD
}

\section{ВИГОТОВЛЕННЯ ДРУКОВАНИХ ПЛАТ ЗА ДОПОМОГОЮ ТЕХНОЛОГІЙ 3D ДРУКУ}

\author{
Igor Sh. Nevliudov \\ igor.nevliudov@nure.ua \\ ORCID: 0000-0002-9837-2309 \\ Danila S. Bliznyuk \\ danylo.blyzniuk@nure.ua \\ ORCID: 0000-0002-3041-1885

\section{Dmytro V. Gurin} \\ dmytro.gurin@nure.ua \\ ORCID: 0000-0002-2272-5227 \\ Dmytro A. Nikitin \\ dmytro.nikitin@nure.ua \\ ORCID: 0000-0002-5591-4438 \\ Yevgen A. Razumov-Frizyuk \\ ievgenii.razumov-fryziuk@nure.ua \\ ORCID: 0000-0001-7426-3805 \\ Roman E. Strelets \\ roman.strilets@nure.ua \\ ORCID: 0000-0001-5123-8703
}

І. Ш. Невлюдов,

д-р. техн. наук, професор, зав. каф. КІТАМ

Д. С. Близнюк,

лаборант каф. КІТАМ

Д. В. Гурін,

ac. каф. KITAM

Д. О. Нікітін,

ас. каф. KITAM

С. А. Разумов-Фризюк,

доц. каф. КІТАМ

Р. С. Стрілець,

лаборант каф. КITAM

Kharkiv National University of Radio Electronics, Kharkiv

Харківський національний університет радіоелектроніки, м. Харків

\begin{abstract}
The variety of radio electronic equipment and the ever-growing mass demand for it put forward new technical requirements, such as miniaturization of equipment, high-modularity of devices. Manufacturers are faced with complex tasks: meeting market requirements, compliance with existing production standards. The modern development of technologies in the field of instrumentation is aimed primarily at miniaturization of devices, and the integration of a large number of modules in one device, in turn, leads to the need to miniaturize both products as a whole and their individual components, assemblies and printed modules.

The miniaturization of the device provides for both a reduction in the size of radio-electronic elements and the size of printed circuit boards (PCBs). The photolithography technology for the production of PCBs is the most consistent with the requirements However, the very process of manufacturing boards using this technology is laborious and requires additional costs for creating stencils, the use of which, in turn, does not allow quickly rebuilding production to create new products. With the current pace of automated production, this lack of flexibility is a significant drawback.

One of the ways to solve these problems can be the development of methods for adapting and optimizing the technological parameters of exposing the PCB topology, using additive 3D printing technology is an urgent topic, which can provide not only a solution to the problems posed, but also provide the necessary parameters of the product, such as:

- preservation of geometric reconciliation of PCB topology;

- positioning accuracy of conductors;

- ensuring the electrical reliability of the PP;

- maintaining the mechanical stability of the conductors;

- avoidance of defects in the PCB topology.

This article discusses the possibilities of using additive technology for 3D printing of boards using photopolymer SLA, DLP and LCD printers. The technology proposed in the article, which allows to combine the production processes of masking and exposure in one stage, differs from the traditional method of photolithography. The article describes the
\end{abstract}


principle of the experimental setup. In the course of the experiment, a test printed circuit board was fabricated using a photopolymer mask method, the quality of which (etching of the ends of the tracks, deviation of geometric dimensions during etching) was compared with a board made using a photoresist film.

Key words: photolithography; exposure; additive technologies; DLP; SLA; LCD; photo masks; production.

Анотація. Різноманіття радіоелектронної техніки та зростаючий масовий попит на неї висувають такі нові технічні вимоги, як мініатюризація апаратури, багатомодульність пристроїв. Перед виробниками постають складні завдання: задоволення вимог ринку, відповідність існуючим стандартам виробництва. Сучасний розвиток технологій в області приладобудування насамперед спрямований на мініатюризацію пристроїв і інтеграцію в одному пристрої великої кількості модулів, що призводить до необхідності мініатюризації як виробів загалом, так і їхніх окремих компонентів, вузлів і друкованих модулів.

Мініатюризація пристрою передбачає зменшення як розмірів радіоелектронних елементів, так і габаритів друкованих плат (далі - ДП). Технологія фотолітографії для виробництва ДП найбільше відповідає поставленим вимогам. Однак процес виготовлення плат за такою технологією трудомісткий і вимагає додаткових витрат на створення трафаретів, використання яких не дозволяє швидко перелаштовувати виробництво на створення нових виробів. При сучасних темпах автоматизованого виробництва відсутність подібної гнучкості є істотним недоліком.

Одним зі способів вирішення цих проблем можуть стати розробки методів адаптації та оптимізації технологічних параметрів експонування топології ДП з використанням адитивних технологій 3D друку. Це актуальна тема, яка може забезпечити не тільки вирішення поставлених проблем, а й такі необхідні параметри виробу:

- збереження геометричних розмірів топології ДП;

- точність позиціонування провідників;

- забезпечення електричної надійності ДП;

- збереження механічної стійкості провідників;

- уникнення дефектів у топології ДП.

У цій статті розглянуто можливості застосування адитивних технологій 3D-друку плат із застосуванням фотополімерних принтерів SLA, DLP i LCD. Запропонована технологія дозволяє об'єднати виробничі процеси нанесення маски та експонування, що відрізняється від традиційного методу фотолітографії. У статті описано принцип дії експериментальної установки. Під час експерименту методом фотополімерної маски була виготовлена тестова друкована плата, якість якої (травлення торців доріжок, відхилення геометричних розмірів при травленні) порівняли з платою, виконаною з використанням фоторезистивної плівки.

Ключові слова: фотолітографія; експонування; адитивні технології; DLP; SLA; LCD; фото-маски; виробництво.

\section{ПОСТАНОВКА ЗАДАЧІ}

Основною задачею дослідження $є$ розробка технології створення провідникової топології друкованих плат 3 використанням технологій SLA та DLP 3D-друку.

\section{АНАЛІЗ ОСТАННІХ ДОСЛІДЖЕНЬ І ПУБЛІКАЦІЙ}

На початковому етапі процесу фотолітографії поверхню, що обробляється, покривають фоторезистом, який наносять за допомогою аерозолю, або наклеюють фоточутливу полімерну плівку. Потім через фотошаблон із заданою топологією плати фоторезист засвічується. Далі експоновані ділянки видаляються у проявник. Одержаний малюнок на фоторезисті використовується для подальших технологічних етапів: травлення, електроосадження, вакуумного напилення або інших. Після проведення одного з цих процесів залишки фоторезисту при прояві також видаляються (рис. 1).

Експонування може проводитися як із використанням фотошаблону, так і без нього (безмасочна літографія). В останньому випадку малюнок на фото- резисті формується шляхом переміщення лазерної плями або електронним променем чи їх групою, сфокусованим на поверхні фоторезисту. При застосуванні фотошаблонів здебільшого використовуються проекційні методи експонування, коли малюнок із фотошаблону переноситься на фоторезист з використанням системи оптичних лінз [1]. Таким чином, процес фотолітографії складається із таких послідовних етапів: нанесення фоторезисту на виріб, експонування фотошаблону на оброблювану поверхню з подальшим травленням.

\section{ВІДОКРЕМЛЕННЯ НЕ ВИРІШЕНИХ РАНІШЕ ЧАСТИН ЗАГАЛЬНОЇ ПРОБЛЕМИ}

Для кожного етапу необхідне вузькоспеціалізоване обладнання та витратні матеріали. Дорогі складні в обслуговуванні габаритні верстати (наприклад, установки для прямого експонування UVE-M500, UVE-M720, COLIGHT DMVL 1630) не можуть використовувати невеликі підприємства.

При виробництві великих партій кожний етап займає значну кількість часу, а при нанесенні фоторезисту аерозолем потрібен час ще й для просушки 


\section{АВТОМАТИЗАЦІЯ ТА КОМП'ЮТЕРНО-ІНТЕГРОВАНІ ТЕХНОЛОГІЇ № 4 2020}

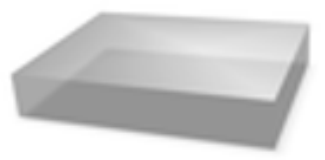

Підготовка

поверхні

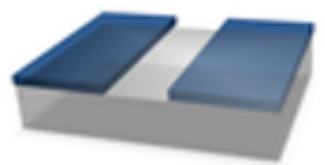

Проявлення

фоторезиста

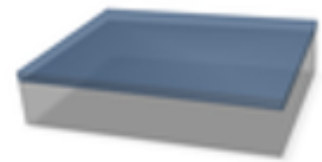

Нанесення

фоторезиста

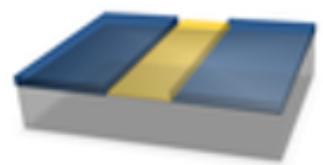

Обробка поверхні (травлення, електроосадження, та інше)

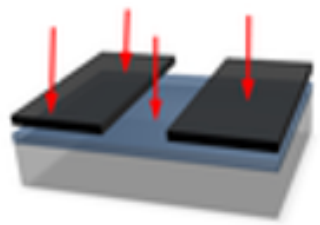

Експонування
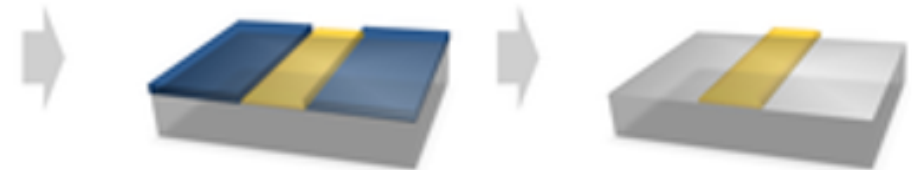

Видалення

фоторезиста

Рис. 1. Спрощена схема фотолітографії для друкованих плат

виробів. На кожному етапі можуть виникнути дефекти на виробі в результаті помилки оператора або технічного збою обладнання. Для мінімізації цих негативних факторів необхідний більш високий рівень автоматизації, який би забезпечував контроль і синхронну роботу основного і допоміжного обладнання. До того ж на стадії травлення можливі геометричні відхилення отриманого зображення від вихідної топології ДП, наприклад підтравлювання провідникових доріжок.

Поява технологій адитивного виробництва (3D-друку) дозволяс по-новому подивитися на вирішення цієї проблеми. Технології DLP (Digital Light Processing), SLA (Laser stereolithography) та LCD-друку можна використовувати для маскування окремих ділянок фольгованого діелектрика для подальшого травлення провідникової системи. Таке обладнання дає можливість швидкого переналаштування для виробництва нових виробів, забезпечуючи високу точність виготовлення.

\section{МЕТА ДОСЛІДЖЕННЯ}

Метою роботи $є$ адаптація технологій 3D-друку SLA та DLP для створення топології друкованих плат на фольгованих діелектриках і порівняння якості провідникових доріжок ДП, отриманих із фотополімерних трафаретів і фоторезестивної плівки.

\section{МЕТОДИ, ОБ'СКТ ТА ПРЕДМЕТ ДОСЛІДЖЕННЯ}

Об'єкт дослідження - процес експонування топологічних зображень друкованих плат.

Предмет дослідження - технологічні параметри SLA та DLP для експонування топології друкованих плат.

\section{ОСНОВНИЙ МАТЕРІАЛ}

Нині технології друку фотополімерними смолами та порошковими матеріалами одні із найбільш популярних для точного прототипування порівняно з іншими технологіями адитивного виробництва, оскільки вони дозволяють виготовляти 3 високою точністю деталі різного призначення [2].

Існує кілька технологій засвічування полімеру в фотополімерних принтерах. 3 них можна виділити три основних:

1. SLA-технологія (Selective Laser Sintering).

Спосіб адитивного виробництва (3D-друку) під назвою «стереолітографія» полягає в послідовній полімеризації тонких шарів рідкого фоточутливого полімеру променем ультрафіолетового лазера малої потужності. У робочій ємності $3 \mathrm{D}$-принтера розташована платформа, занурена в рідку смолу. Спочатку платформа знаходиться біля поверхні полімеру. Вона покрита тонким шаром від 20 мікронів до 150 мікрон, на якому лазер починає формувати шар деталі [3]. Модель нарізується на тонкі шари, рівні роздільній здатності принтера по вертикальній осі. Створивши один шар, принтер занурює платформу на товщину нового шару моделі (від 10 мкм до 150 мкм) і створюе наступний шар (рис. 2).

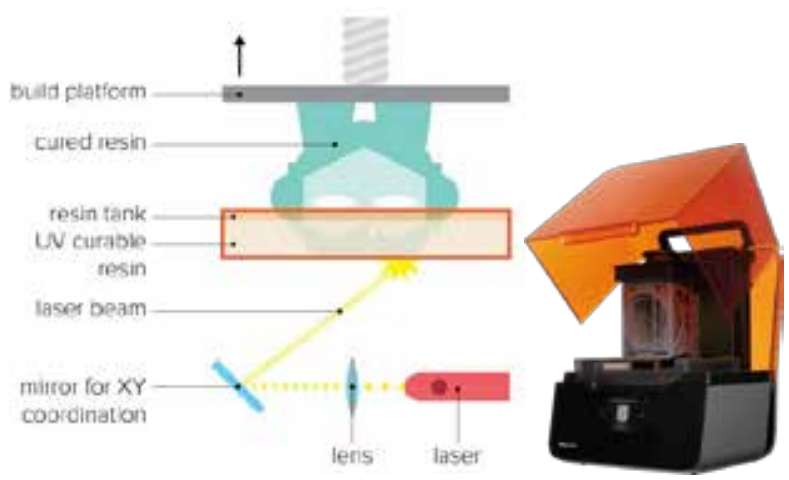

Рис. 2. Схема роботи SLA-принтера 
Під впливом лазера (його потужність може бути відносно невеликою, що робить принтер дешевшим за апарати, які працюють із порошковими матеріалами SLS, SLM) полімер твердне, утворюючи стінки майбутнього виробу. Так шар за шаром і створюється модель. Якщо в ній є навісні елементи, то для них вибудовуються підтримки 3 того ж полімеру, який потім механічно видаляється. Підтримки в моделі передбачають і створюють у CAD-програмах на стадії проектування моделі [4].

2. DLP-технологія (Digital Light Processing).

Принцип роботи 3D-принтерів, які використовують технологію 3D-друку DLP, схожий на роботу проектора. Полімер переходить у тверду форму під дією світла (видимого спектру), причому засвічується відразу весь шар [5]. Потік світла модулюється системою MEMS - мікромеханічними дзеркалами, кожне $з$ яких керується окремо. Залежно від положення дзеркала світло або проходить у певну точку шару, або ні. Тобто машина має фіксоване логічне розширення - кількість точок по координатах XY [6]. Їх фізичний розмір залежить від того, на якій відстані від джерела випромінювання в системі мікродзеркал перебуває модель (рис. 3).

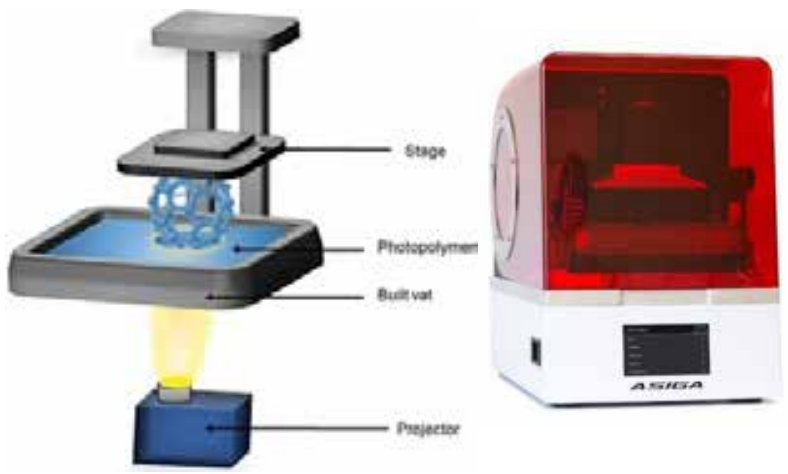

Рис. 3. Схема роботи DLP-принтера

\section{LCD-технологія.}

Принтер із засвіченням фотополімеру світлодіодною УФ-матрицею 3 використанням маски LCDдисплея (рис. 4).

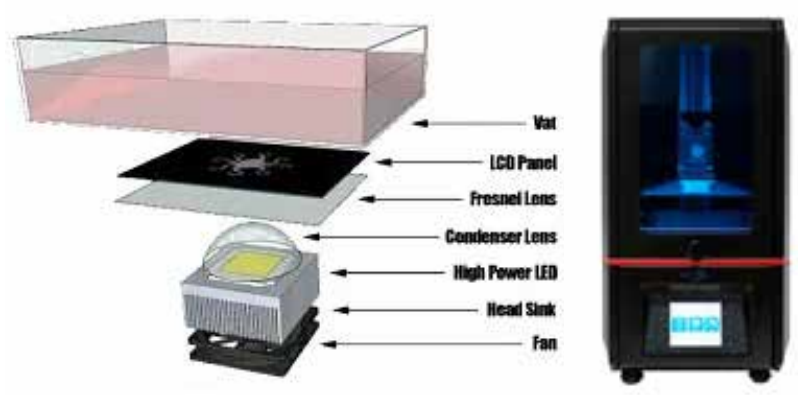

Рис. 4. Схема роботи LCD-принтера

Фотополімер засвічується світлодіодною матрицею. Зображення формується за рахунок LCDдисплея, який покадрово виводить переріз формованої деталі. Якщо відмінності класичної SLAтехнології від DLP і LCD очевидні, то DLP і LCDтехнології засвічування часто плутають, хоча кожна 3 цих технологій має свої особливості, які впливають на можливості принтера, якість друку. У табл. 1 наведено порівняння SLA-, DLP- і LCD-технологій [7].

Застосування цих технологій 3D-друку дозволить створювати на фольгованому діелектрику маскувальний шар для подальшого травлення. Як маскуючий матеріалу використовуються фотополімерні смоли, які є хімічно інертними щодо більшості травників. Таким чином за рахунок технологій фотополімерного 3D-друку можна створювати повністю готову маску необхідної товщини і конфігурації.

Використання 3D-друку дозволить виробляти ДП, які відповідають вимогам класів точності ДСТУ 53429-2009 від першого до п’ятого класу, наприклад, плати під мікроконтролери на базі Arduino та Raspberry (табл. 2). Для практичної реалізації
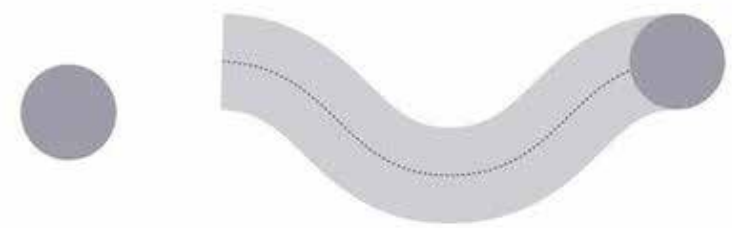

Разрешение в плоскости X-Y при печати на SLA 3d принтере зависит от диаметра пятна используемого УФ-лазера
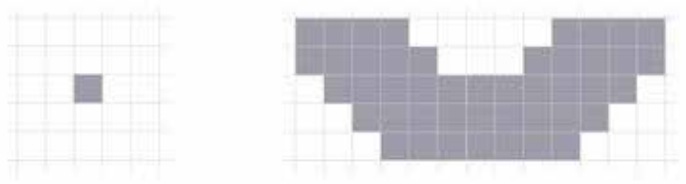

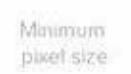

Разрешение в плоскости X-Y при печати на DLP $3 d$ принрете зависит от разрешения проектора

Рис. 5. Роздільна здатність SLA та DLP / LCD 


\section{АВТОМАТИЗАЦІЯ ТА КОМП'ЮТЕРНО-ІНТЕГРОВАНІ ТЕХНОЛОГІЇ № 4〜 2020}

Таблиця 1. Порівняння SLA-, DLP- і LCD-технологій [7]

\begin{tabular}{|c|c|}
\hline Технологія & Особливості \\
\hline \multicolumn{2}{|r|}{ 1. Розмір області друку по XY } \\
\hline SLA & $\begin{array}{c}\text { Не обмежений. Чим вищою є область друку, тим нижчою є швидкість (променю необхідно встигну- } \\
\text { ти «оббігти» велику площу }\end{array}$ \\
\hline DLP & $\begin{array}{c}\text { Не обмежений. Чим вищою є область друку, тим нижчою є швидкість друку і роздільна здатність } \\
\text { принтера }\end{array}$ \\
\hline LCD & Область друку жорстко прив’язана до розміру LCD-дисплея \\
\hline \multicolumn{2}{|r|}{ 2. Швидкість друку } \\
\hline SLA & $\begin{array}{c}\text { Це «найповільніша» із трьох технологій, що пов’язано із послідовним засвіченням і низькою } \\
\text { потужністю лазера }\end{array}$ \\
\hline DLP & Це «найшвидша» технологія, що зумовлено високою потужністю проектора \\
\hline LCD & $\begin{array}{c}\text { «Середня» по швидкості друку технологія. Швидкість друку пов’язана з потужністю УФ-матриць. } \\
\text { Потужність матриці збільшувати нескінченно не можна, тому що потужні матриці вимагають по- } \\
\text { тужного охолодження і починають «пробивати» «трафарет» і3 LCD-дисплея }\end{array}$ \\
\hline \multicolumn{2}{|r|}{ 3. Паразитне засвічення по осі Z } \\
\hline SLA & Мінімальне \\
\hline DLP & $\begin{array}{c}\text { Максимальне. Високий ступінь засвічення пов'язаний як із великою потужністю ламп проектора, } \\
\text { так і з більшою часткою довгохвильового актинічного випромінювання в спектрі }\end{array}$ \\
\hline LCD & Середнє \\
\hline \multicolumn{2}{|r|}{ 4. Паразитне засвічення по XY } \\
\hline SLA & Мінімальне \\
\hline DLP & При правильному наведенні на різкість мінімальне, але вище, ніж у SLA \\
\hline LCD & $\begin{array}{l}\text { Максимальне. Сильне паразитне засвічення пов'язана із засвіченням сусідніх пікселів за рахунок } \\
\text { недосконалості, сфокусовані системою УФ-матриці (точніше з її повною відсутністю, коли світло на } \\
\text { маску потрапляє під різними кутами). У майбутньому цей недолік, ймовірно, буде виправлений }\end{array}$ \\
\hline \multicolumn{2}{|r|}{ 5. Фактори, що впливають на роздільну здатність (крім властивостей полімеру і товщини шару) } \\
\hline SLA & $\begin{array}{l}\text { 1. Діаметр плями лазера і точність позиціонування плями. Типові значення від } 100 \text { мкм до } 200 \text { мкм } \\
\text { (для плями лазера), від } 40 \text { мкм до } 20 \text { мкм (точність позиціонування). } \\
\text { 2. На 3D-принтерах із технологією SLA можна друкувати, наприклад, об’єкти із дуже тонкими вер- } \\
\text { тикальними стінками товщиною всього } 100 \text { мікрон, горизонтальний шар може становити від } 30 \text { мкм } \\
\text { до } 50 \text { мкм. }\end{array}$ \\
\hline DLP / LCD & $\begin{array}{l}\text { 1. Розмір пікселя і точність наведення на різкість. Типовий дозвіл становить } 1920 \text { х 1080, розмір } \\
\text { пікселя залежить від області друку по XY. } \\
\text { 2. Менший дозвіл порівняно із SLA-принтерами, оскільки зображення в них формується крізь } \\
\text { піксельну матрицю (від } 33 \text { мкм до } 47 \text { мкм), що не дозволяє досягти більш плавних контурів деталі } \\
\text { порівняно із SLA-технологіями (рис. 5). }\end{array}$ \\
\hline \multicolumn{2}{|r|}{ 6. Ціна } \\
\hline SLA & $\begin{array}{l}\text { Ціни на бюджетні моделі коливаються в межах 2500-5300 доларів, «професійні» ж коштують від } \\
5300 \text { доларів і вище }\end{array}$ \\
\hline DLP & Ціни на серійні зразки складають 4000 доларів і вище \\
\hline LCD & Ціна складає 400-700 доларів \\
\hline
\end{tabular}

Таблиця 2. ДСТУ 53429-2009 для друкованих плат [8]

\begin{tabular}{|c|c|c|c|c|c|c|c|}
\hline \multirow{2}{*}{ Найменування параметру Найменші номінальні значення розмірів для класу точності } \\
\cline { 2 - 8 } & $\mathbf{1}$ & $\mathbf{2}$ & $\mathbf{3}$ & $\mathbf{4}$ & $\mathbf{5}$ & $\mathbf{6}$ & $\mathbf{7}$ \\
\hline Ширина провідника & 0,75 & 0,45 & 0,25 & 0,15 & 0,10 & 0,075 & 0,050 \\
\hline Відстань між провідниками & 0,75 & 0,45 & 0,25 & 0,15 & 0,10 & 0,075 & 0,050 \\
\hline $\begin{array}{c}\text { Гарантійний поясок } \\
\text { контактної площадки }\end{array}$ & 0,30 & 0,20 & 0,10 & 0,05 & 0,025 & 0,020 & 0,015 \\
\hline $\begin{array}{c}\text { Наявність металевого по- } \\
\text { криття }\end{array}$ & \multicolumn{7}{|c|}{ Граничне відхилення розмірів малюнка характерне для класу точності } \\
\hline & 1 & 2 & 3 & 4 & 5 & 6 & 7 \\
\hline Без покриття & $\pm 0,15$ & $\pm 0,10$ & $\pm 0,05$ & $\pm 0,03$ & $\pm 0,03$ & $\pm 0,02$ & $\pm 0,015$ \\
\hline З покриттям & $\begin{array}{c}+0,25 \\
-0,15\end{array}$ & $\begin{array}{c}+0,15 \\
-0,10\end{array}$ & $\pm 0,10$ & $\pm 0,05$ & $+0,03$ & $\pm 0,02$ & $\pm 0,015$ \\
\hline
\end{tabular}


Таблиця 3. ДСТУ 53429-2009 для друкованих плат [8]

\begin{tabular}{|c|c|c|c|c|c|c|c|}
\hline \multirow{2}{*}{ Вид друкованої плати } & \multicolumn{6}{|c|}{ Позиційний допуск розташування друкованого провідника для класу точності } \\
\cline { 2 - 8 } & $\mathbf{1}$ & $\mathbf{2}$ & $\mathbf{3}$ & $\mathbf{4}$ & $\mathbf{5}$ & $\mathbf{6}$ & $\mathbf{7}$ \\
\hline $\begin{array}{c}\text { ОДП, ДДП, МДП } \\
\text { (зовнішній шар) }\end{array}$ & 0,20 & 0,10 & 0,05 & 0,03 & 0,02 & 0,01 & 0,005 \\
\hline МПП & & & & & & & \\
\hline (внутрішній шар) & 0,30 & 0,15 & 0,10 & 0,08 & 0,05 & 0,02 & 0,01 \\
\hline
\end{tabular}

розглянутих технологій необхідно розробити програмне забезпечення, яке дозволило б контролювати процес експонування, адаптувати топологічний рисунок ДП з урахуванням технологічних параметрів і можливих виробничих дефектів.

Розглянемо процес фотоекспонування за допомогою DLP-технології і запропонованої конструкції «масочного» принтера (рис. 6).

Горизонтальна каретка (2), на якій встановлений захоплюючий механізм (6), захоплює фольговану гетенаксову або стеклотекстолитову заготовку (7), пересувається по горизонтальній осі за допомогою ШВП і крокової двигуна (3). Досягнувши потрібного положення по горизонталі та опустившись донизу за допомогою ШВП (11) і крокових двигунів вертикальної осі (12), каретка переносить заготовку (7) у ванну (9) із фотополімерною смолою (8), опускає заготовку на глибину 20 мкм від прозорого дна ванни (13). Потім включається DLP-проектор із УФ-випромінюванням (15), через оптичну систему дзеркал (14) зображення подається на прозоре дно ванни (13).

У результаті полімеризації смоли під дією випромінювання засвічені ділянки топології застигають і прилипають до заготівлі. Так створюється трафарет майбутньої плати. Каретка із полімеризованою заготовкою піднімається вгору. Поворотний механізм (4) кілька разів плавно, під невеликим кутом нахиляє заготовку, щоб у ванну стекли надлишки незастиглої смоли. Готова заготовка переміщається в контейнер (10) з ізопропиловим спиртом для очищення від

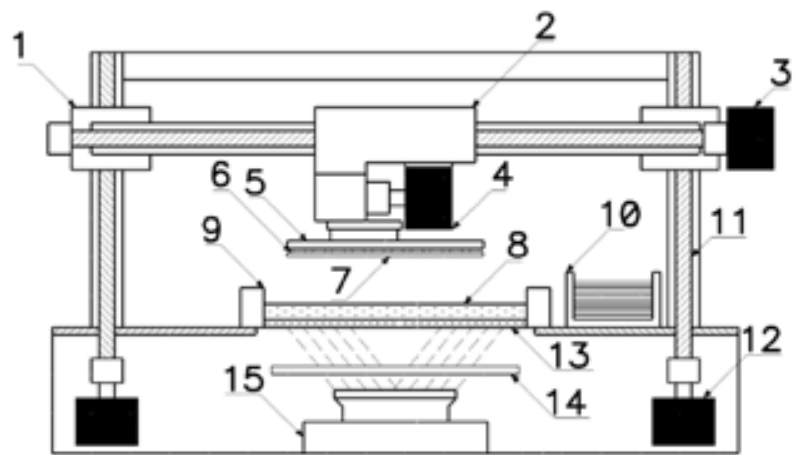

Рис. 6. Схема конструкції «масочного» принтера на основі DLP-технології: 1 - карета вертикальної осі; 2 - каретка горизонтальній осі; 3 - кроковий двигун горизонтальній осі; 4 - двигун поворотного механізму; 5 - підставка механізму захоплення плат; 6 - захватний механізм; 7 - заготовка; 8 - фотополімерна смола; 9 - ванна для фотополімера; 10 - короб для полімеризованих заготовок; 11 - ШВП; 12 - крокові двигуни вертикальних осей; 13 - прозора плівка дно ванною; 14 - оптична система дзеркал; 15 - DLP-проектор

\section{Класичні етапи фотолітографії}

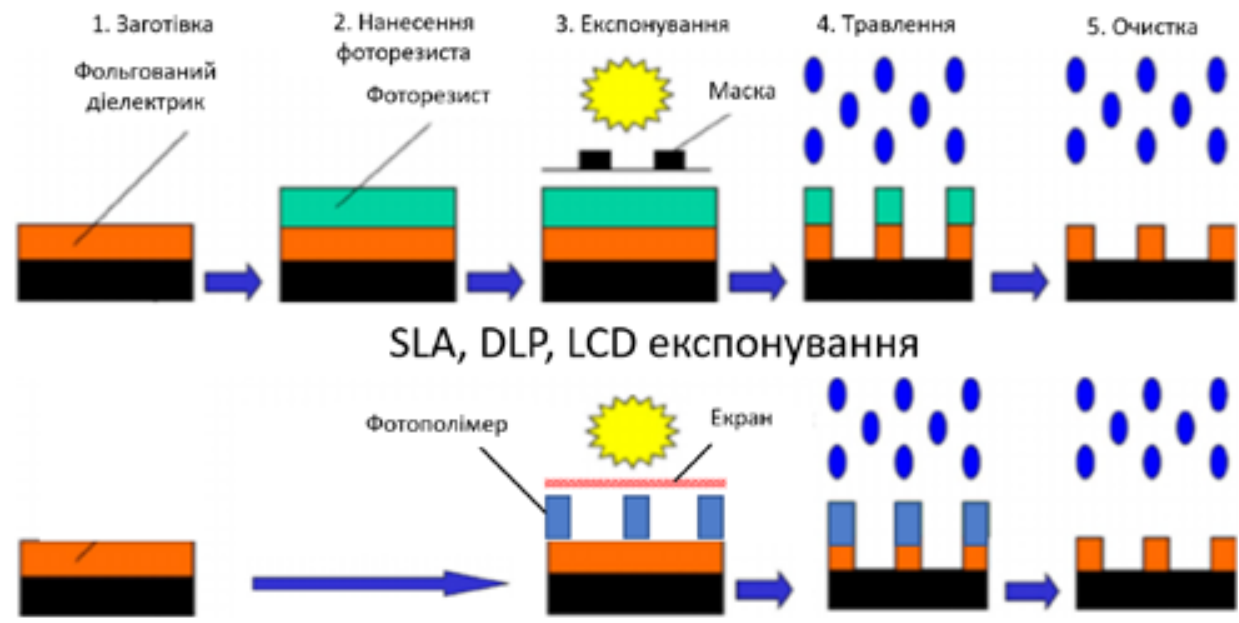

Рис. 8. Етапи 3D-експонування масок 


\section{АВТОМАТИЗАЦІЯ ТА КОМП'ЮТЕРНО-ІНТЕГРОВАНІ ТЕХНОЛОГІЇ № 4〜 2020}

залишків рідкого полімеру. На наступному технологічному етапі заготовки плат протравлюються, після чого із заготовок знімаються фотополімерні маски. Таким чином при використанні технологій фотополімерного 3D-друку можна одночасно виконувати етап нанесення маски та експонування (рис. 8).

Цей підхід може бути реалізований за допомогою SLA- або LCD-технологій друку та має такі переваги:

- установка експонує задану топологію на заготовку без попереднього нанесення фоторезистивних плівок або аерозолів;

- немає необхідності у двох окремих установках для нанесення фоторезистора і експонування усе здійснюється одночасно на одній установці, що дозволяє розвантажити виробничі площі;

- оскільки час засвічення фотополімера становить 3-7 секунд, що менше часу засвічення фоторезистивних плівок, то збільшується загальна продуктивність.

3 огляду на цей принцип був проведений експеримент із виготовлення ДП за допомогою LCDтехнології. Створену 3D-топологію провідників ДП розміром $40 \times 40$ мм перенесли на фольгований склотекстоліт (марки СФ ДСТУ 10316-78) та протравили в розчинні хлорного заліза (FeCl3) (рис. 9).

Цей експеримент показав, що такий підхід до виготовлення ДП можна реалізувати, але він вимагає додаткових досліджень та оптимізації технологічних параметрів. Підібравши необхідну потужність і тривалість засвічення та врахувавши особливості фотополімера, можна досягти необхідних вимог ДСТУ для ДП.

\section{ВИСНОВКИ}

Проведений експеримент показав, що при використанні технології фотополімерного 3D-друку можна переносити зображення топології на ДП, об’єднавши процеси нанесення фоторезистора та експонування топології в одній установці. Під час експерименту спостерігалася добра адгезія полімеризованого фотополімерами до поверхні заготовки ДП, в результаті чого при хімічному травленні вдалося уникнути протравлення торців доріжок, на відміну від результатів застосування класичних фоторезистивних плівок (рис. 10). На заключному етапі очищення плати фотополімерний трафарет легко знімається з поверхні, не пошкоджуючи провідникові доріжки.

Використання адитивних технологій 3D-друку дозволяє:

- значно спростити і здешевити виготовлення ДП, виключивши з виробничого процесу етап нанесення фоторезистора на заготовку;
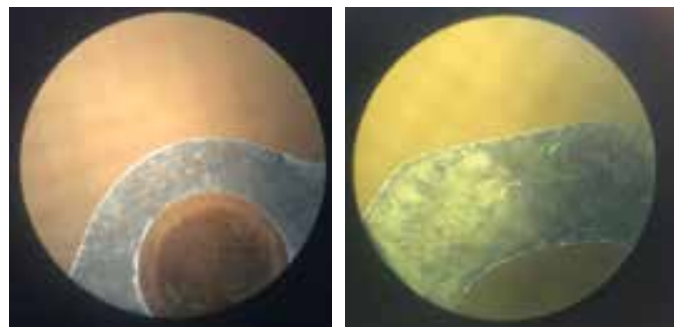

a)
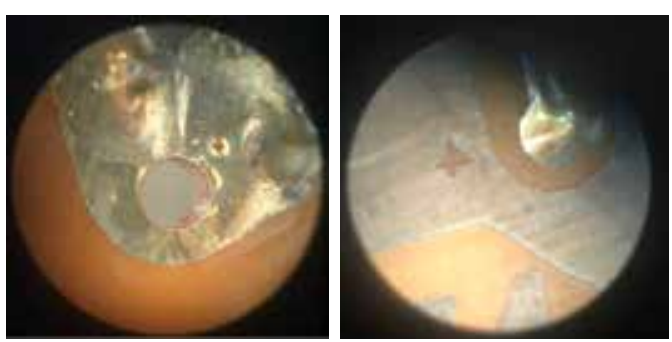

б)

Рис. 10. Порівняння результатів торців доріжок після травлення ДП: $a$ ) - торці доріжок провідників з використанням фотополімерної маски; б) - торці доріжок провідників з використанням фоторезистивної плівки

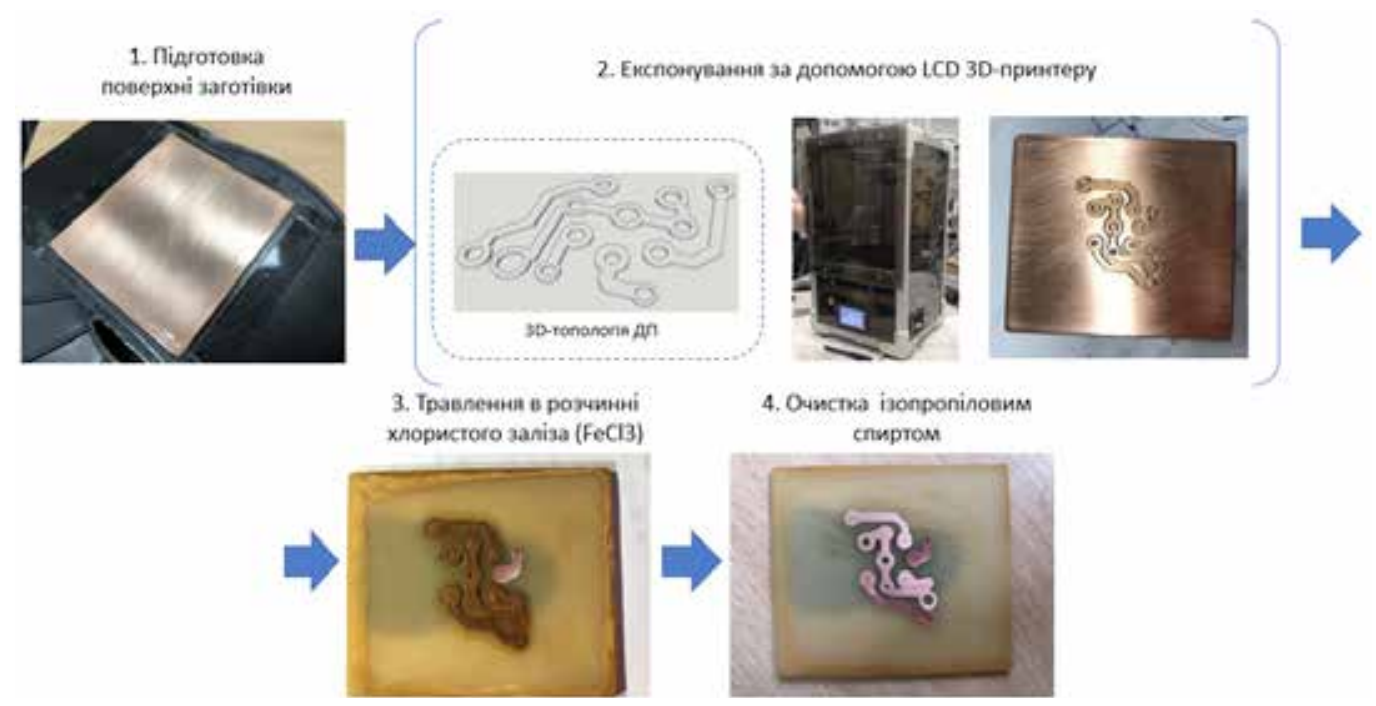

Рис. 9. Виготовлення топології ДП за допомогою LCD-принтера 
- ефективніше використовувати виробничі площі;

- адаптувати вихідну топологію ДП, враховуючи вплив технологічних факторів (за наявності відповідного програмного забезпечення);

- досягти високої точності виготовлення провідників.
Подальший розвиток запропонованої технології дозволить виготовляти жорсткі та гнучкі електронні плати зі струмопровідними доріжками, діелектричною основою, радіоелектронними елементами, які можуть застосовуватися в різних пристроях $[9 ; 10]$.

\section{REFERENCES}

[1] Zelentsov S.V., Zelentsova N.V. Modern photolithography. Educational and methodological material for the advanced training program "New materials for electronics and optoelectronics for information and telecommunication systems". Nizhny Novgorod, 2006, $56 \mathrm{p}$.

[2] 3D-printing. A Practical Guide / Redwood Ben, Garrat Brian, Chauffeur Philemon. M. : DMK-Press, 2020. 220 p.

[3] SL / SLA (stereolithography) [Electronic resource]; access mode (https://www.jetcom-3d.ru/technology/stereolithography/); Victory date: 03.11.2020.

[4] Manapat J., Chen Q., Ye P., Advincula R. (2017) 3D-printing of polymer nanocomposites via stereolithography. Macromol Mater Eng 302: 1600553.

[5] DLP (Digital Light Processing) [Electronic resource]; access mode (https://www.jetcom-3d.ru/technology/digital-light-processing/); Victory date: 03.11.2020.

[6] Alfred Jacobsen, Trond Jorgensen, Øyvind Tafjord, Endre Kirkhorn "Concepts for 3D print productivity systems with advanced DLP photoheads", Proc. SPIE 9376, Emerging Digital Micromirror Device Based Systems and Applications VII, 937605.

[7] Modern photopolymer printers 3D-printers: laser, DLP, LCD [Electronic resource]; access mode (https://3dtoday.ru/blogs/ $\mathrm{pl32/modern-photopolymer-3d-printersprinters-laser-dlp-lcd).} \mathrm{Victorian} \mathrm{date:} \mathrm{05.11.2020.}$

[8] DSTU 53429-2009 documentation go to the spheres of science and technology structure and formatting rules [Text] Introduction. 2010.07.01. K. : Derzhstandart of Ukraine, 2010. 29 p.

[9] Nevlyudov I.Sh., Palagin V.A., Razumov-Frizyuk E.A., Zharikova I.V. "Design of technological equipment for the control of microcircuits of products of microcircuit technology”. Modern science research, ideas, results, technologies. № 2(15), $2014.71 \mathrm{p}$.

[10] Microelectromechanical bagatozondovy pidmikalny pristrij: pat. 95190 Ukraine: IPC N05K 3/40/ Nevlyudov I.Sh., Palagin V.A., Razumov-Frizyuk C.A., Zharikova I.V. ta in., Publ. 11.07.2011. Bull. № 13.

\section{СПИСОК ВИКОРИСТАНОЇ ЛІТЕРАТУРИ}

[1] Зеленцов С.В., Зеленцова Н.В. Современная фотолитография. Учебно-методический материал по программе повышения квалификации «Новые материалы электроники и оптоэлектроники для информационно-телекоммуникационных систем». Нижний Новгород. 2006, 56 с.

[2] 3D-печать. Практическое руководство / Рэдвуд Бен, Гаррэт Брайан, Шофер Филемон. М. : ДМК-Пресс, 2020. 220 с.

[3] SL/SLA (стереолитография) [Електронний ресурс] Режим доступу: https://www.jetcom-3d.ru/technology/ stereolithography/. Дата звернення: 03.11.2020.

[4] Manapat J., Chen Q., Ye P., Advincula R. (2017) 3D-printing of polymer nanocomposites via stereolithography. Macromol Mater Eng 302:1600553.

[5] DLP (Digital Light Processing) [Електронний pecypc] Режим доступу: https://www.jetcom-3d.ru/technology/digital-lightprocessing/. Дата звернення: 03.11.2020.

[6] Alfred Jacobsen, Trond Jorgensen, Øyvind Tafjord, Endre Kirkhorn "Concepts for 3D-print productivity systems with advanced DLP photoheads", Proc. SPIE 9376, Emerging Digital Micromirror Device Based Systems and Applications VII, 937605.

[7] Современные фотополимерные принтеры 3D-принтеры: лазерные, DLP, LCD. [Електронний ресурс] Режим доступу: https://3dtoday.ru/blogs/pl32/modern-photopolymer-3d-printersprinters-laser-dlp-lcd. Дата звернення: 05.11.2020.

[8] ДСТУ 53429-2009 Документація, звіти у сфері науки і техніки: структура і правила оформлення [Текст] Введ. 2010.07.01. К. : Держстандарт України, 2010. 29 с.

[9] Невлюдов И.Ш., Палагин В.А., Разумов-Фризюк Е.А., Жарикова И.В. «Проектирование технологической оснастки для контроля микросхем изделий микросхемной техники». Современная наука исследования, идеи, результаты, технологии. № 2(15). 2014. 71 с.

[10] Мікроелектромеханічний багатозондовий підмикальний пристрій: пат. 95190 України: МПК Н05К 3/40/ Невлюдов І.Ш., Палагін В.А., Разумов-Фризюк С.А., Жарікова І.В. та ін., опубл. 11.07.2011. Бюл. № 13. 